\title{
PENGARUH PENGGUNAAN FILLER ASBUTON DENGAN FILLER FLY ASH TERHADAP ASPAL BETON LAPIS AUS $(A C-W C)$ DITINJAU DARI NILAI KARATERISTIK MARSHALL
}

\author{
Asrullah $^{1)}$, Alhilal Sukoco ${ }^{2)}$ \\ Program Studi Teknik Sipil Fakultas Teknik Universitas Palembang \\ email : asrull66@yahoo.co.id
}

\begin{abstract}
ABSTRAK
Lapis aus (wearing course) merupakan lapisan jalan paling atas yang banyak menerima dampak langsung baik dari beban lalu lintas ataupun dari perubahan iklim. Lapis aus terdiri dari agregat yang lebih halus dengan kadar aspal lebih tinggi dari lapisan yang lainnya. Kekuatan aspal beton banyak ditentukan oleh batuan yang memberi dukungan terhadap stabilitas. Hal ini disebabkan hampir 92\% dari berat campuran aspal beton terdiri dari agregat, filler dan sisanya aspal yang berfungsi sebagai bahan pengikat antar agregat. Penelitian ini menggunakan metode pengujian Marshall yang bertujuan untuk mengukur pengaruh penggunaan filler terhadap stabilitas, kelelehan (flow) dan Marshall Quotient aspal beton lapis aus ( $A C$ - WC). Pengujian Marshall dari variasi penggunaan filler asbuton dengan filler fly ash dengan variasi 1\%, $2 \%$ dan 3\%. Hasil analisa pengujian Marshall menunjukkan nilai stabilitas tertinggi didapat pada penggunaan filler fly ash $2 \%$ dengan nilai $883,2 \mathrm{~kg}$ dan nilai stabilitas terendah didapat pada penggunaan filler fly ash $1 \%$ dengan nilai $828 \mathrm{~kg}$. Untuk nilai kelelehan (flow) baik filler asbuton maupun filler fly ash masih memenuhi spesifikasi teknik 2010 revisi 3. Untuk nilai rongga udara dalam campuran (VIM) terdapat campuran yang tidak memenuhi spesifikasi yaitu pada campuran tanpa filler dan campuran dengan filler fly ash $1 \%$
\end{abstract}

Kata kunci : Asbuton, Fly Ash, AC- WC, Karakteristik Marshall

\section{PENDAHULUAN}

Salah satu sarana transportasi adalah jalan yang merupakan kebutuhan pokok dan menunjang dalam kegiatan aktivitas masyarakat. Dengan melihat peningkatan pertumbuhan mobilitas penduduk yang sangat tinggi, maka diperlukan peningkatan baik nilai strukturnya maupun kualitas mutu, jalan yang digunakan untuk memenuhi kegiatan dan aktivitas kebutuhan penduduk.

Karakteristik aspal beton banyak dipengaruhi oleh bahan yang digunakan untuk campurannya, gradasi campuran dan pelaksanaan yang baik dilapangan, sedangkan kekuatan aspal beton

banyak ditentukan oleh batuan yang dalam proses campuran (komposisi) sangat menentukan karateristik dari aspal beton tersebut. untuk meningkatkan kemampuan dan suatu perkerasan adalah dengan material - material tertentu baik itu terhadap aspal maupun pada agreagat [1].

Penelitian ini dilakukan dengan menambah zat materil dalam hal ini berupa asbuton berbutir dan Fly ash yang difungsikan sebagai bahan pengganti (filler) agar menghasilkan aspal beton yang memenuhi persyaratan. 
Tujuan penelitian adalah mengetahui campuran yang tepat dan pengaruh pengunaan asbuton berbutir dengan Fly ash sebagai pengganti( filler) ditinjau dari stabilitas, kepadatan serta keawetan dan kekuatan juga terhadap kerusakan campuran . dengan mengunakan $1 \%, 2 \%$ dan $3 \%$ dalam campuran Asphalt panas $(A C-W C)$. Untuk mengetahui kualitas perkerasan tersebut jika digunakan pada perkerasan lentur jalan raya.

Aspal beton campuran panas merupakan salah satu jenis dari lapis perkerasan konstruksi perkerasan lentur. Jenis perkerasan ini merupakan campuran merata antara agregat dan aspal sebagai bahan pengikat pada suhu tertentu [1]

\section{TINJAUAN PUSTAKA}

\subsection{Klasifikasi Aspal Beton}

A. Berdasarkan fungsinya aspal beton campuran panas dapat diklasifikasikan sebagai berikut [1] :

1. Sebagai lapis permukaan yang tahan terhadap cuaca, gaya geser, dan tekanan roda serta memberikan lapis kedap air yang dapat melindungi lapis dibawahnya dari rembesan air.

2. Sebagai lapis pondasi atas.

3. Sebagai lapis pembentuk pondasi, jika dipergunakan pada pekerjaan peningkatan atau pemeliharaan.

B. Berdasarkan metode pencampurannya, aspal beton dapat dibedakan atas:

1. Aspal beton Amerika, yang bersumber kepada Asphalt Institute.

2. Aspal beton durabilitas tinggi, yang bersumber pada BS 594, Inggris, dan dikembangkan oleh CQCMU, Bina Marga, Indonesia.

\subsection{Karakteristik Aspal Beton}

Terdapat 7 (tujuh) karakteristik campuran yang harus dimilki aspal beton [2] sebagai berikut :

1. Stabilitas

Stabilitas lapisan perkerasan jalan adalah kemampuan suatu perkerasan jalan menerima beban lalu lintas tanpa adanya perubahan bentuk seperti gelombang, alur roda serta naiknya permukaan aspal. Kestabilan yang terlalu tinggi menyebabkan lapisan itu menjadi kaku dan cepat mengalami retak, disamping itu karena volume antar agregat kurang mengakibatkan kadar aspal yang dibutuhkan rendah. Stabilitas terjadi dari hasil gesekan antar butir, penguncian antar partikel daya ikat yang baik dari lapisan aspal

2. Durabilitas (keawetan/daya tahan)

Durabilitas merupakan ketahanan lapisan permukaan terhadap pengaruh cuaca, air dan perubahan suhu maupun keausan gesekan roda kendaraan. Durabilitas yang tinggi umumnya dicapai dengan kadar aspal yang tinggi, gradasi agreagat rapat dan pemadatan yang baik.

3. Fleksibilitas (kelenturan)

Fleksibilitas adalah kemampuan lapisan permukaan untuk dapat mengikuti deformasi yang terjadi akibat beban lalu lintas berulang tanpa timbulnya retak dan perubahan lainnya.

4. Tahanan geser/kekesatan (skid resistance)

Tahanan Geser adalah kekesatan

yang diberikan oleh perkerasan, sehingga

kendaraan tidak mengalami slip diwaktu hujan atau basah kering. Kekesatan

dinyatakan dengan koefisien gesek antar pemukaan jalan dan ban kendaraan

5. Kedap air (impermeabilitas )

Impermeabilitas merupakan

kemampuan permukaan perkerasan untuk menahan rembesan air kedalam permukaan sehingga memberikan perlindungan terhadap konsrtruksi pada lapis bawah.

6. Kemudahan pelaksanaan (workability)

Adalah mudahnya suatu campuran untuk dihampar dan dipadatkan sehingga diperoleh hasil yang memenuhi kepadatan yang di harapkan

7. Ketahanan kelelehan (fatique resistance)

Merupakan ketahanan dari lapis aspal dalam menerima beban berulang tanpa terjadi kelelehan yang berupa alur (ruting) dan retak

Agregat adalah partikel mineral yang berbentuk butiran - butiran yang merupakan salah satu pengunaan dalam kombinasi dengan berbagai macam tipe mulai dari sebagai bahan material di semen untuk membentuk beton, lapis pondasi jalan, material pengisi dan lain- lainnya. Beberapa tipikal ketentuan penggunaan dalam penggambaran agregat [3]: 
1. Fine aggregate (sand size/ukuran pasir) sebagaian besar partikel agregat berukuran antara $4,75 \mathrm{~mm}$ (no. 4 sieve test) dan $75 \mu \mathrm{m} \quad$ (no. 200 sieve test).

2. Coarse aggregate (gravel size/ukuran kerikil) : sebagian besar agregat berukuran lebih besar dari 4,75 mm (no. 4 sieve test).

3. Crushed gravel : pit gravel (kerikil dengan pasir atau batu bulat) yang mana telah didapatkan dari salah satu alat pemecah untuk menghancurkan banyak partikel batu yang berbentuk bulat untuk menjadikan ukuran yang lebih kecil atau untuk memproduksi lapisan kasar (raugher surfaces).

4. Crushed rock : agregat dari pemecahan batuan. Semua bentuk partikel tersebut bersiku-siku/tajam (angular) tidak ada bulatan dalam material tersebut.

5. Screenings : kepingan-kepingan dan debu bubuk yang merupakan produksi dalam pemecahan dari batuan (bedrock) untuk agregat.

Sifat agregat yang menentukan kualitas sebagai bahan konstruksi perkerasan jalan dapat dikelompokan menjadi 3 (tiga) kelompok yaitu [3] :

1. Kekuatan dan keawetan (strength and durability) lapisan yang dipengaruhi oleh gradasi, ukuran maksimum, kadar lempung, kekerasan dan ketahanan (toughness and durability) bentuk butiran serta tekstur permukaan.

2. Kemampuan dilapisi aspal dengan baik, yang mempengaruhi oleh porositas kemungkinan basah dan jenis agregat yang digunakan.

3. Kemudahan dalam pelaksanaan dan menghasilkan lapisan yang nyaman dan aman, yang dipengaruhi oleh tahanan geser (skid resistance) serta campuran yang memberikan kemudahan dalam pelaksanaan (bituminous mix workability).

Secara umum agregat yang digunakan dalam campuran beraspal dibagi atas dua fraksi [3] yaitu:

1. Agregat kasar

Fraksi agregat kasar untuk rancangan campuran adalah yang tertahan ayakan
No. $4(4,75 \mathrm{~mm})$ yang dilakukan secara basah dan harus bersih, keras, awet dan bebas dari lempung atau bahan yang tidak di kehendaki lainnya dan memenuhi ketentuan. Agregat yang digun Agregat halus.

2. Agregat Halus

Fraksi agregat halus adalah material yang lolos saringan No $4(4,175 \mathrm{~mm})$ dan tertahan saringan No. $200(0,075 \mathrm{~mm})$.

Gradasi agregat dapat dibedakan menjadi sebagai berikut [3] :

1. Gradasi seragam (unifrom graded)

Merupakan agregat dengan ukuran yang hampir sama atau sejenis atau mengandung agregat halus yang lebih sedikit jumlahnya sehingga tidak dapat mengisi rongga antar gregat. Gradasi seragam disebut juga gradasi terbuka. Agregat dengan gradasi seragam akan menghasilkan lapisan perkerasan dengan sifat permebilitas tinggi, stabilitas kurang dan berat volume kecil.

2. Gradasi rapat (dense graded)

Merupakan campuran antara agregat kasar dan halus dalam pori seimbang, sehingga dinamakan juga dengan agregat bergradasi baik (well graded). Agregat dengan gradasi rapat akan menghasilkan lapisan perkerasan dengan stabilitas tinggi, kedap air.

3. Gradasi buruk (poorly graded)

Merupakan campuran agregat yang tidak memenuhi dua kategori diatas. Agregat bergradasi buruk umumnya di gunakan untuk lapisan perkerasan lentur yang bergradasi celah (gap graded). Sering juga di sebut dengan gradasi senjang. Agregat dengan gradasi buruk akan menghasilkan lapisan perkerasan yang mutunya terlatak antara ke dua jenis tersebut 
Tabel 1. Gradasi Gabungan Untuk

\section{Campuran Aspal}

\begin{tabular}{|c|c|c|c|c|c|c|c|c|c|}
\hline \multirow{4}{*}{$\begin{array}{c}\text { Ukuran } \\
\text { ayakan } \\
(\mathrm{mm})\end{array}$} & \multicolumn{9}{|c|}{ \% Berat yang lolos terhadap total agregat dalam campuran } \\
\hline & \multicolumn{2}{|c|}{ Latasir } & \multicolumn{4}{|c|}{ Lataston HRS } & \multicolumn{3}{|c|}{ Laston (AC) } \\
\hline & \multirow[b]{2}{*}{$\begin{array}{c}\text { Kelas } \\
\text { A }\end{array}$} & \multirow[b]{2}{*}{$\begin{array}{c}\text { Kelas } \\
\text { B }\end{array}$} & \multicolumn{2}{|c|}{$\begin{array}{l}\text { Gradasi } \\
\text { senjang }\end{array}$} & \multicolumn{2}{|c|}{$\begin{array}{l}\text { Gradasi semi } \\
\text { senjang }\end{array}$} & \multirow[b]{2}{*}{ WC } & \multirow[b]{2}{*}{$\mathrm{BC}$} & \multirow[b]{2}{*}{ Base } \\
\hline & & & WC & Base & WC & Base & & & \\
\hline 37,5 & $\cdot$ & - & $\cdot$ & - & - & $\cdot$ & - & - & 100 \\
\hline 25 & - & - & - & - & $\cdot$ & - & - & 100 & $90-100$ \\
\hline 19 & 100 & 100 & 100 & 100 & 100 & 100 & 100 & $\begin{array}{l}90- \\
100\end{array}$ & $76-90$ \\
\hline 12,5 & - & - & $\begin{array}{l}90- \\
100\end{array}$ & $90-100$ & $\begin{array}{l}87- \\
100\end{array}$ & $\begin{array}{l}90- \\
100\end{array}$ & $\begin{array}{l}90- \\
100\end{array}$ & $75-90$ & $60-78$ \\
\hline 9,6 & $\begin{array}{l}90- \\
100\end{array}$ & - & $75-85$ & $65-90$ & 55-88 & $55-70$ & $77-90$ & $66-82$ & $52-71$ \\
\hline 4,75 & - & - & - & - & - & $\cdot$ & $53-69$ & $46-64$ & $35-54$ \\
\hline 2,36 & - & $75-100$ & $50-72$ & $35-55$ & $50-62$ & $32-44$ & $35-53$ & $30-49$ & $23-41$ \\
\hline 1,18 & - & - & - & - & - & - & $21-40$ & $18-38$ & $13-80$ \\
\hline 0.600 & $\cdot$ & - & $35-60$ & 15-35 & $20-45$ & 15-35 & $14-30$ & $12-28$ & $10-\not 22$ \\
\hline 0,300 & - & . & - & - & $15-35$ & $5-35$ & $99-22$ & $7-20$ & $6-15$ \\
\hline 0,150 & $\cdot$ & $\cdot$ & $\cdot$ & $\cdot$ & $\cdot$ & - & $6-15$ & $5-13$ & $6-10$ \\
\hline 0,075 & $10-15$ & $8-13$ & $6-10$ & $2-9$ & $6-10$ & $4-8$ & $4-9$ & $4-8$ & $3-7$ \\
\hline
\end{tabular}

\subsection{Aspal}

Aspal merupakan senyawa hidrokarbon berwarna coklat gelap atau belum pekat yang dibentuk dari unsur unsur asphalthenes, resins dan oils. Aspal pada lapisan perkerasan berfungsi sebagai bahan ikat antara agregat untuk membentuk suatu campuran yang kompak, sehingga akan memberikan kekuatan masing-masing agregat. Selain sebagai bahan ikat aspal juga berfungsi untuk mengisi rongga butiran agregat dan pori pori yang ada dari agregat itu sendiri [4].

Aspal merupakan bahan pengikat yang berbentuk plastis yang terdiri dari [4] :

1. Aspal alam yang merupakan aspal batuan (rock asphalt) yang berbentuk dari proses alam

2. Ter merupakan residu hasil proses destilasi batubara

3. Aspal minyak dengan dasar dapat di bedakan:

a. Aspal keras (asphalt cement) adalah suatu jenis aspal yang didapat dari hasil residu destilasi minyak bumi pada keadaan hampa udara,

b. Aspal cair (cut back asphalt) merupakan suatu campuran aspal semen dengan bahan pencair hasil destilasi minyak bumi yang pada suhu normal dan tekanan atmosfir berbentuk cair.

c. Aspal emulsi merupakan suatu campuran aspal dan air dengan menambahkan bahan pengemulsi tertentu sehingga air dan aspal dapat di cairkan.

\section{Tabel 2. Ketentuan ketentuan Aspal} Untuk Aspal Keras

\begin{tabular}{|c|c|c|c|c|c|}
\hline \multirow[t]{3}{*}{ No } & \multirow[t]{3}{*}{ Jenis Pengujian } & \multirow[t]{3}{*}{$\begin{array}{c}\text { Metoda } \\
\text { Pengujian }\end{array}$} & \multirow{3}{*}{$\begin{array}{c}\text { Tipe I } \\
\text { Aspal } \\
\text { Pen } 60 / 70\end{array}$} & \multicolumn{2}{|c|}{$\begin{array}{l}\text { Tipe II Aspal Yang } \\
\text { Dimodifikasi }\end{array}$} \\
\hline & & & & A & B \\
\hline & & & & $\begin{array}{c}\text { Asbuton yg } \\
\text { di proses }\end{array}$ & $\begin{array}{c}\text { Elastomer } \\
\text { Sintesis }\end{array}$ \\
\hline 1. & $\begin{array}{l}\text { Penetrasi pada } 25^{\circ} \mathrm{C} \\
(0,1 \mathrm{~mm})\end{array}$ & $\begin{array}{l}\text { SNI-06-2156- } \\
1991\end{array}$ & $60-70$ & $\operatorname{Min} 50$ & $\operatorname{Min} 40$ \\
\hline 2 & $\begin{array}{l}\text { Viskositas Dinamis } \\
60^{\circ} \mathrm{C}(\mathrm{Pa} . \mathrm{s})\end{array}$ & $\begin{array}{l}\text { SNI-06-6441- } \\
2000\end{array}$ & $160-240$ & $240-360$ & $320-480$ \\
\hline 3 & $\begin{array}{l}\text { Viskositas kinematis } \\
135^{\circ} \mathrm{C}(\mathrm{cSt})\end{array}$ & $\begin{array}{l}\text { SNI-06-6441- } \\
2000\end{array}$ & $\geq 300$ & $385-200$ & $\leq 300$ \\
\hline 4 & Titik lembek ( $\left.{ }^{\circ} \mathrm{C}\right)$ & SNI-2434:2011 & $\geq 48$ & $\geq 53$ & $\geq^{54}$ \\
\hline 5 & $\begin{array}{l}\text { Daktilitas pada } \\
25^{\circ} \mathrm{C},(\mathrm{cm})\end{array}$ & SNI-2432:2011 & $\geq 100$ & $\geq 100$ & $\geq 100$ \\
\hline 6 & Titik nyala $\left({ }^{\circ} \mathrm{C}\right)$ & SNI-2432:2011 & $\geq 232$ & $\geq 232$ & $\geq 232$ \\
\hline 7 & $\begin{array}{l}\text { Kelarutan dalam } \\
\text { Trichlorocthylene(\%) }\end{array}$ & $\begin{array}{l}\text { ASSHTO T44- } \\
03\end{array}$ & $\geq 99$ & $\geq 99(1)$ & $\geq 99$ \\
\hline 8 & Berat jenis & SNI2441:2011 & $\geq 1,0$ & $\geq 1,0$ & $\geq 1,0$ \\
\hline 9 & $\begin{array}{l}\text { Stabilitas } \\
\text { Penyimpanan: } \\
\text { perbedaan Titilk } \\
\left.\text { Lembek( }{ }^{\circ} \mathrm{C}\right)\end{array}$ & $\begin{array}{l}\text { ASTMD } 5976 \\
\text { part } 6.1\end{array}$ & & $\leq 2,2$ & $\leq 2,2$ \\
\hline 10 & $\begin{array}{l}\text { Partikel yang lebih } \\
\text { halus dari } 150 \text { micro } \\
\text { (jam)(\%) }\end{array}$ & & & $\operatorname{Min} 95(1)$ & \\
\hline & $\begin{array}{l}\text { Pengujian Residu hasil T } \\
\text { 2002) }\end{array}$ & $\mathrm{DT}(S N Z-06-2$ & II) ata & $\operatorname{TFOT}(S N$ & -6835- \\
\hline 11 & Berat yang Hilang(\%) & $\begin{array}{l}\text { SNI-06-2441- } \\
1991\end{array}$ & $\leq 0,8$ & $\leq 0,8$ & $\leq 0,8$ \\
\hline 12 & $\begin{array}{l}\text { Viskositas dinamis } \\
60^{\circ} \mathrm{C}(\mathrm{Pa} . \mathrm{s})\end{array}$ & $\begin{array}{l}\text { SNI-03-6441- } \\
2000\end{array}$ & $\leq 800$ & $\leq 1200$ & $\leq 1600$ \\
\hline 13 & $\begin{array}{l}\text { Penetrasi pada } 25^{\circ} \mathrm{C} \\
(0,1 \mathrm{~mm})\end{array}$ & $\begin{array}{l}\text { SNI-06-2456- } \\
1991\end{array}$ & $\geq^{54}$ & $\geq^{54}$ & $\geq^{54}$ \\
\hline 14 & $\begin{array}{l}\text { Dakttilitias Pada } 25^{\circ} \mathrm{C} \text {, } \\
\text { (cm) }\end{array}$ & $\begin{array}{l}\text { SNI_2434:201 } \\
1\end{array}$ & $\geq 100$ & $\geq^{50}$ & $\geq 25$ \\
\hline 15 & $\begin{array}{l}\text { Keelastian setelah } \\
\text { pengembalian (\%) }\end{array}$ & $\begin{array}{l}\text { AASHTO T } \\
301-98\end{array}$ & & & $\geq 60$ \\
\hline
\end{tabular}

\subsection{Bahan Pengisi}

Bahan pengisi (filler) dapat menggunakan abu batu (stone dust). Bahan pengisi (filler) harus kering dan bebas dari gumpalan-gumpalan dan merupakan bahan yang $75 \%$ lolos ayakan no. 200 dan mempunyai sifat non plastis. Bahan pengisi ini memiliki fungsi [4]:

1. Sebagai pengisi rongga antara partikel agregat yang lebih besar, sehingga rongga udara menjadi lebih kecil dan menghasilkan tahan gesek serta penguncian antar butiran yang tinggi. Dengan demikian akan meningkatkan stabilitas campuran.

2. Jika ditambahkan kedalam aspal, bahan pengisi akan menjadi suspensi, sehingga terbentuk mastic yang bersama sama dengan aspal mengikat partikel agregat. Dengan penambahan bahan pengisi, aspal 
menjadi lebih kental dan campuran agregat aspal menjadi bertambah kekuatanya.

\subsection{Aspal Buton (Asbuton)}

Aspal Buton (asbuton) adalah aspal alam yang terkandung dalam deposit batuan yang terdapat di pulau Buton Sulawesi Tenggara dan sekitarnya yang mengandung mineral dan aspal dengan kadar bervariasi. Dengan jumlah deposit Asbuton yang mencapai 650 juta ton menjadikan Indonesia sebagai negara penghasil aspal alam terbesar di dunia. Kadar aspal yang terkandung dalam Asbuton bervariasi, antara 10-40\%. Ini merupakan kadar aspal yang cukup besar dibandingkan dengan kadar aspal alam negara-negara lain seperti $(12-15) \%$ dan Prancis (6-10)\% Dari segi mutu Asbuton dirasa masih kalah bersaing dengan aspal minyak. Kadar aspal asbuton yang bervariasi, mudah pecah [5].

Asbuton saat ini dinilai lebih murah dan efisien. Asbuton juga memilki kelebihan, yaitu titik lembeknya lebih tinggi dari aspal minyak dan ketahanan Asbuton cukup tinggi terhadap panas, sehingga membuatnya tidak cepat mudah meleleh. Sesuai dengan keluarnya Peraturan Menteri PU No. 35/2006, saat ini pemerintah bertekad untuk menggalakan penggunaan Asbuton pada pekerjaan perbaikan pembangunan dan peningkatan jalan [5]

Tabel 3. Jenis Asbuton Berbutir

\begin{tabular}{|c|c|c|c|c|c|c|c|}
\hline $\begin{array}{l}\text { Sifat sifat asbuton } \\
\text { berbutir }\end{array}$ & $\begin{array}{l}\text { Metoda } \\
\text { pengujian }\end{array}$ & $5 / 20$ & $15 / 20$ & $15 / 25$ & $20 / 25$ & $30 / 25$ & $60 / 30$ \\
\hline $\begin{array}{l}\text { Kadar bitumen } \\
\text { asbuton \% }\end{array}$ & $\begin{array}{c}\text { SNI 03-3640- } \\
1994\end{array}$ & $18-22$ & $18-22$ & $23-27$ & $23-27$ & $23-27$ & $25-30$ \\
\hline \multicolumn{8}{|c|}{ Ukuran butiran asbuton butir } \\
\hline $\begin{array}{l}\text { lolos saringan No } \\
4(4,75 \mathrm{~mm}) ; \%\end{array}$ & $\begin{array}{c}\text { SNI-03-1968- } \\
1990\end{array}$ & & & & 100 & 100 & 100 \\
\hline $\begin{array}{l}\text { lolos saringan No } \\
8(2,36 \mathrm{~mm}) ; \%\end{array}$ & $\begin{array}{c}\text { SNI-03-1968- } \\
1990\end{array}$ & 100 & 100 & 100 & $\begin{array}{l}\text { Min } \\
95\end{array}$ & $\begin{array}{l}\text { Min } \\
95\end{array}$ & $\cdot$ \\
\hline $\begin{array}{l}\text { lolos saringan No } \\
16(1,18 \mathrm{~mm}) ; \%\end{array}$ & $\begin{array}{c}\text { SNI-03-1968- } \\
1991\end{array}$ & $\begin{array}{l}\text { Min } \\
95\end{array}$ & $\begin{array}{l}\text { Min } \\
95\end{array}$ & $\begin{array}{l}\text { Min } \\
95\end{array}$ & $\begin{array}{l}\text { Min } \\
75\end{array}$ & $\begin{array}{c}\text { Min } \\
75\end{array}$ & $\cdot$ \\
\hline Kadar air \% & $\begin{array}{c}\text { SNI_06-2490- } \\
1991\end{array}$ & Mak 2 & Mak 2 & Mak 2 & Mak 2 & Mak 2 & Mak 2 \\
\hline $\begin{array}{l}\text { Penetrasiaspal } \\
\text { asbuton pada } 25^{\circ} \mathrm{C} \text {, } \\
100 \mathrm{~g}, 5 \text { detik, } 0,1 \\
\mathrm{~mm}\end{array}$ & $\begin{array}{c}\text { SNI 06-2456- } \\
1991\end{array}$ & $0-10$ & $10-18$ & $10-18$ & $19-22$ & $28-32$ & \begin{tabular}{c|c} 
Min \\
60
\end{tabular} \\
\hline \multicolumn{2}{|l|}{ Aplikasi } & v & v & v & $x$ & $x$ & $x$ \\
\hline \multicolumn{2}{|l|}{ Campuran panas } & v & 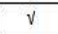 & $v$ & $v$ & v & $x$ \\
\hline \multicolumn{2}{|l|}{ Campuran hangat } & v & v & v & v & $v$ & $x$ \\
\hline \multicolumn{2}{|l|}{ Penetrasimacadam } & $x$ & $x$ & $x$ & $x$ & $x$ & V \\
\hline
\end{tabular}

\subsection{Abu Batu bara (Fly Ash)}

Fly ash adalah limbah industri yang di hasilkan dari pembakaran batubara dan terdiri dari partikel yang halus. Gradasi dan kehalusan fly ash batubara dapat memenuhi persyaratan American Association of State Highway and Transportasion Officials designation M17 (AASTHO M17) untuk mineral filler. Fly ash atau abu terbang yang merupakan sisa sisa pembakaran batubara, yang dialirkan dari ruang pembakaran melalui ketel berupa semburan asap [6].

Penggunaan fly ash dalam berbagai kebutuhan konstruksi di dasari oleh pertimbangan [6]:

1. Tehnik (manfaat yang diperoleh dari sifat dan properti/karakter material fly ash)

2. Lingkungan (memanfaatkan limbah untuk kepentingan yang berguna)

3. Ekonomi (menghasilkan produksi yang lebih murah)

Karateristik fisik dan kimia fly ash batu bara [6] adalah Specific gravity, rentang terbesar yang diberikan dari institusi tersebut adalah 1,6 - 3.1. pada umumnya specific gravity material fly ash berkisar 1,9-2,55. Massa jenis fly ash dalam kondisi lose berkisar $540-860 \mathrm{~kg} / \mathrm{m}^{3}$, dalam kondisi dipadatkan dengan penggetaran dalam kemasan pada umumnya mempunyai massa jenis $1.120-1.500 \mathrm{~kg} / \mathrm{m}^{3}$. Sifat fisik abu terbang (fly ash) batubara antara lain densitinya $2,23 \mathrm{gr} / \mathrm{cm}^{3}$.

Tabel 4. Kandungan Logam berat Pada Abu Batu Bara

\begin{tabular}{|l|l|c|c|c|c|c|}
\hline \multirow{2}{*}{ No } & Jenis Abu Batubara & \multicolumn{5}{|c|}{$\begin{array}{c}\text { Kandungan Logam Berat } \\
\text { (ppm) }\end{array}$} \\
\cline { 3 - 8 } & & $\mathrm{Cu}$ & $\mathrm{Pb}$ & $\mathrm{Zn}$ & $\mathrm{Cd}$ & $\mathrm{Cr}$ \\
\hline 1 & Abu Batubara BukitA Asam & 298 & 19 & 391 & 11 & 224 \\
\hline 2 & AbuBatubara Ombilin & 87 & 15 & 153 & 11 & 120 \\
\hline
\end{tabular}


Tabel 5. Komposisi Abu Terbang (Fly ash) Batu bara

\begin{tabular}{|l|c|}
\hline \multicolumn{1}{|c|}{ Kandungan } & Persentase (\%) \\
\hline $\mathrm{SiO}_{2}$ & 57,95 \\
$\mathrm{Al}_{2} \mathrm{O}_{3}$ & 28,15 \\
$\mathrm{Fe}_{2} \mathrm{O}_{3}$ & 4,75 \\
$\mathrm{TIO}_{2}$ & 0,93 \\
$\mathrm{CaO}$ & 3,74 \\
$\mathrm{MgO}$ & 1,73 \\
$\mathrm{~K}_{2} \mathrm{O}$ & 0,62 \\
$\mathrm{Na}_{2} \mathrm{O}$ & 0,48 \\
$\mathrm{P}_{2} \mathrm{O}_{5}$ & 0,81 \\
$\mathrm{SO}_{3}$ & 0,28 \\
$\mathrm{MnO}_{2}$ & 0,07 \\
$\mathrm{Undeterminated}$ & 0,49 \\
\hline
\end{tabular}

Sumber: Data Analisis Abu Batubara PLTU PT. Bukit Asam (persero)

\subsection{Metode Marshall}

Prinsip dasar metode marshall adalah pemeriksaan Stabilitas dan kelelehan (flow) serta analisis kepadatan dan pori dari campuran padat yang terbentuk.

Tabel 6. Karateristik Campuran

\begin{tabular}{|c|c|c|c|c|c|c|c|}
\hline \multirow[t]{3}{*}{ Cara pemeriksaan } & \multicolumn{6}{|c|}{ Persyaratan } & \multirow[t]{3}{*}{ Satuan } \\
\hline & \multicolumn{2}{|c|}{ L.L Berat } & \multicolumn{2}{|c|}{ L.L Sedang } & \multicolumn{2}{|c|}{ L.L Ringan } & \\
\hline & Min & Maks & Min & Maks & Min & Maks & \\
\hline Stability & 800 & - & 450 & - & 350 & - & $\mathrm{kg}$ \\
\hline $\begin{array}{l}\text { Rongga dalam } \\
\text { campuran }\end{array}$ & 3 & 8 & 3 & 8 & 3 & 8 & $\%$ \\
\hline Rongga terisi aspal & 65 & 75 & 65 & 75 & 65 & 75 & $\%$ \\
\hline kelelehan & 2 & 4 & 2 & 4,5 & 2 & 5 & $\mathrm{~mm}$ \\
\hline Iumlah tumbukan & \multicolumn{2}{|c|}{$2 \times 75$} & \multicolumn{2}{|c|}{$2 \times 50$} & \multicolumn{2}{|c|}{$2 \times 35$} & \\
\hline
\end{tabular}

\section{METODOLOGI PENELITIAN}

\subsection{Jenis Penelitian}

Penelitian ini dilakukan di laboratorium yaitu dengan melakukan pengujian Marshall. Data yang diperoleh dari penelitian ini adalah data kuantitatif berupa data rasio.

\subsection{Teknik Pengumpulan Data}

Data data yang digunakan dalam penelitian ini adalah data primer dan data sekunder [7].

1. Data Primer

Data data hasil pengujian marshall baik yang menggunakan variatif dalam penggunaan filler asbuton berbutir dan variatif dalam penggunaan filler fly ash.
Data data yang digunakan dalam penelitian ini adalah Design Mix Formula $(D M F)$ aspal beton lapisan aus $(A C-W C)$

\section{HASIL DAN PEMBAHASAN 4.1. Berat Jenis/Bulk Density}

Kepadatan adalah berat campuran yang diukur tiap satuan volume, kepadatan menunjukan tingkat kerapatan campuran setelah dipadatkan. Faktor faktor yang mempengaruhi kepadatan adalah kualitas bahan penyusun, energi pemadatan dan kadar aspal dalam campuran. Hasil penelitian dilaboratorium di dapat nilai sebagai berikut.

Untuk campuran $A C$ - $W C$ normal tanpa filler dengan filler asbuton variasi dan filler fly Ash variasi. Didapat kepadatan dengan nilai tertinggi pada penggunaan filler asbuton $3 \%$ dengan nilai $2,282 \mathrm{gr} / \mathrm{cm}^{3}$ untuk $A C W C$ aspal penetrasi 60/70. Sedangkan untuk filler yang menggunakan fly ash $3 \%$ dengan nilai $2,262 \mathrm{gr} / \mathrm{cm}^{3}$ untuk $A C-W C$ aspal penetrasi 60/70. Sedangakan pada campuaran yang tanpa menggunakan filler dengan nilai $2,240 \mathrm{gr} / \mathrm{cm}^{3}$ untuk $A C-W C$ aspal penetrasi 60/70. Untuk berat isi tidak ada persyaratan khusus yang dikeluarkan oleh Bina Marga mengenai kepadatan ini. Dengan semakin tinggi nilai kepadatan akan didapatkan kualitas campuran yang semangkin baik. Hal ini dapat dijelaskan dengan kepadatan yang tinggi dari suatu campuran aspal panas akan semakin kadap air dan udara [9]

\section{Gambar 1. Grafik Bulk Density}

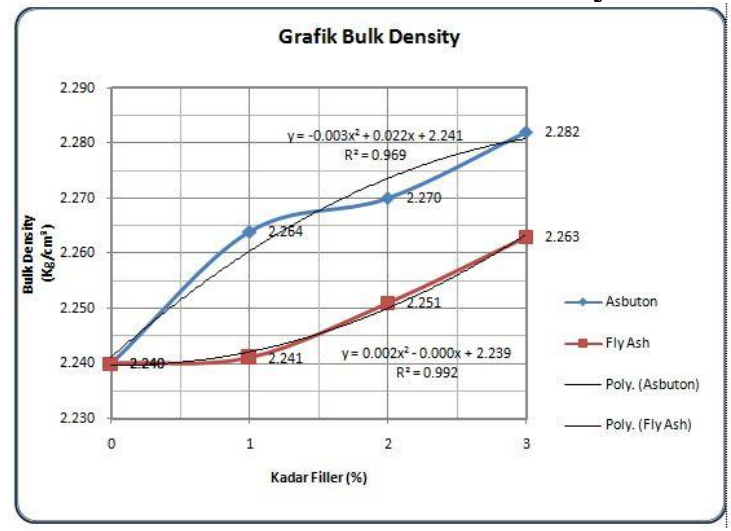

Sumber : Hasil Analisa 2017

2. Data sekunder 


\subsection{Rongga Udara Dalam Agregat (Void In Mineral Agregate/VMA)}

Rongga udara dalam agregat (VMA) adalah banyaknya pori diantara butiran butiran agregat dalam campuran aspal yang dinyatakan dalam persentase. Nilai rongga udara dalam agregat yang kecil dapat mengakibatkan aspal yang menyelimuti agregat terbatas sehingga kemudian agregat terlepas menjadikan lapisan tidak kedap air, oksidasi mudah terjadi sehingga lapisan perkerasan mudah rusak. Dari hasil pengujian didapat nilai sebagai berikut:

Bahwa rongga udara dalam campuran dengan nilai tertinggi, terdapat pada campuran tanpa filler dengan nilai $17,90 \%$ kemudian pada filler fly ash $1 \%$ dengan nilai $17,88 \%$, sedangakan nilai terendah terdapat pada filler asbuton $2 \%$ didapat nilai $16,36 \%$. Untuk penggunaan filler asbuton, filler fly ash dan tanpa filler rongga udara dalam campuran masih memenuhi yang disyaratkan yaitu $>15 \%$ [8]. Nilai rongga udara dalam campuran akan menentukan keawetan lapisan perkerasan.

Gambar 2. Grafik Rongga Terhadap Agregat

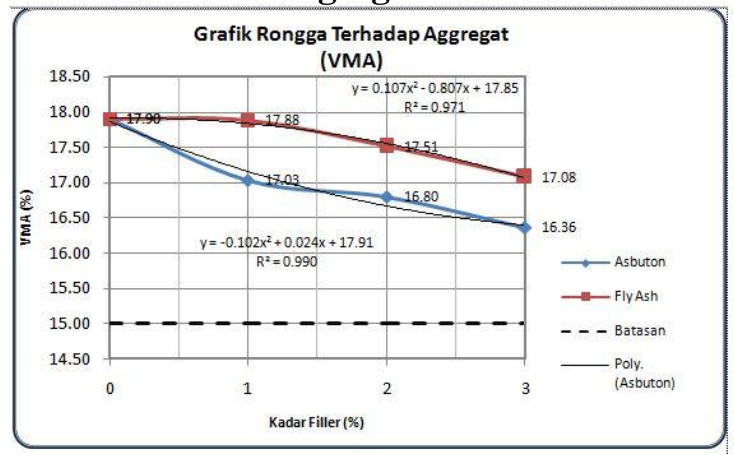

Sumber : Hasil Analisa 2017

\subsection{Rongga udara dalam campuran (Void In The Mix/VIM)}

Nilai rongga udara dalam campuran menunjukan banyaknya rongga yang ada dalam campuran. Nilai rongga udara dalam campuran mempengaruhi sifat kekedapan campuran. Nilai rongga udara dalam campuran yang besar menunjukan banyaknya rongga pada campuran sehingga campuran kurang rapat atau kurang kedap terhadap air maupun udara sehingga oksidasi muda terjadi. Jika nilai rongga udara dalam campuran kecil menunjukan campuran terlalu rapat atau padat dan mempunyai kekakuan tinggi yang akan mengakibatkan naiknya aspal permukaan (bleeding) akibat pemadatan oleh beban lalu lintas terjadi dan pergeseran permukaan aspal (sliding). Dari hasil pengujian didapat nilai sebagai berikut:

Nilai rongga udara dalam campuran $(V I M)$ ada penurunan perubahan nilai dengan penambahan filler baik dari filler asbuton berbutir maupun dengan filler fly ash bila dibandingkan tanpa filler pada campuran $A C$ $W C$. Perubahan penurunan nilai rongga udara dalam campuran (VIM) tidak seiring dengan perubahan penggunaan filler yang bervariasi pada campuaran. Campuran $A C$ $W C$ tanpa filler didapat nilai 5,50\%. Dan pada penggunaan filler fly ash penurunan relatif kecil pada penggunaan filler $1 \%$ didapat nilai 5,49 dan pada filler 2\% didapat nilai 5,00 kemudian pada filler 3\% di dapat nilai $4,56 \%$.

Bila dibandingkan dengan filler asbuton perubahannya baik seiring dengan penambahan persen filler, filler $1 \%$ didapat nilai $4,38 \%$ dan pada filler $2 \%$ didapat nilai $4,24 \%$ kemudian pada filler 3\% didapat nilai $3,74 \%$. Secara keselurahan nilai rongga udara dalam campuran (VIM) yang memenuhi persyaratan, nilai yang disyaratkan adalah $3,0 \%-5.0 \%$ [5]. Bila dilihat dari gambar atas yang memenuhi hanya dari filler $2 \%$ dan $3 \%$ pada filler fly ash dan 1\%, 2\% dan 3\% memenuhi persyaratan [8]. Diluar dari batasan tersebut campuran di anggap gagal, tidak memenuhi. Dalam suatu campuran haruslah tersedia cukup rongga yang terisi udara yang fungsinya untuk menyediakan ruang gerak bagi unsur-unsur campuran sesuai dengan sifat elastisnya.

\section{Gambar 3. Grafik Rongga Terhadap}

\section{Campuran}

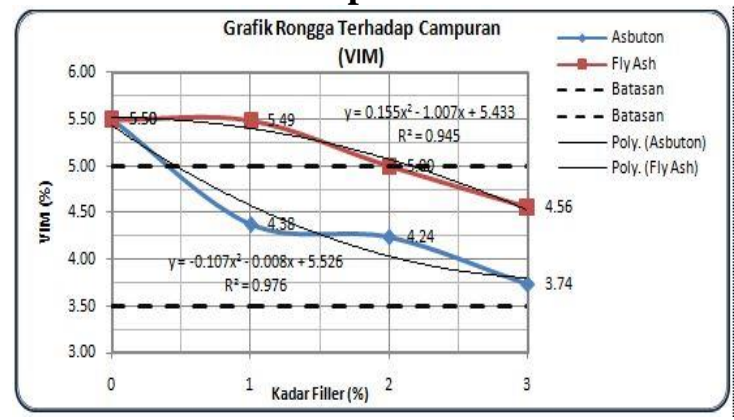

Sumber : Hasil Analisa 2017 


\subsection{Rongga Udara Terisi Aspal (Void Filled with Bitumen/VFB)}

Rongga udara terisi aspal (VFB) menunjukan persentase rongga dalam campuran yang terisi aspal. Nilai rongga udara terisi aspal menentukan nilai stabilitas, durabilitas dan fleksibilitas campuran yang dipengaruhi oleh gradasi agregat, suhu pemadatan, kadar aspal, jenis aspal dan energi pemadatan. Dari pengujian didapatkan hasil sebagai berikut:

Nilai $V F B$ dari campuran yang tanpa menggunakan filler, baik yang mengunakan filler asbuton maupun yang menggunakan filler fly ash masih memenuhi persyaratan [8] dengan batasan $>65 \%$. Hanya terdapat perbedaan yang relatif kecil antara penggunaan fly ash $1 \%$ dengan nilai $69,34 \%$ dengan campuran tanpa filler didapat nilai $69,29 \%$. Sedangkan untuk nilai tertinggi $V F B$ terdapat pada filler asbuton $2 \%$ dengan nilai $77,18 \%$. Untuk nilai terendah dengan tanpa menggunakan filler didapat nilai 69,29\%. Nilai rongga udara terisi aspal ini erat kaitanya dengan kekakuan ikatan campuran, kekedapan campuran terhadap air dan udara, maupun sifat elastisitas campuran yang menentukan kekuatan dan ketahanan terjadinya alur pada lapisan perkarasan.

\section{Gambar 4. Grafik Rongga Terisi Aspal}

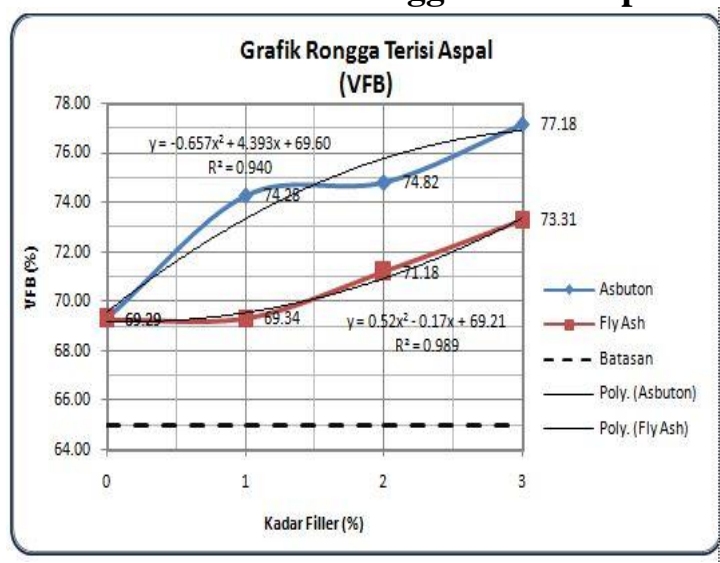

Sumber : Hasil Analsia 2017

\subsection{Stabilitas}

Nilai stabilitas adalah kemampuan lapisan untuk menerima beban lalu lintas tanpa terjadi perubahan alur, bekas roda, gelombang dan bleeding pada pekerasan tersebut. Hal hal yang memberi pengaruh pada campuran $A C$ - $W C$ adalah gesekan, sifat saling mengunci, bentuk material dan dipengaruhimjuga oleh tekstur permukaan agregat, gradasi agregat, bentuk partikel, kepadatan campuran dan viskositas aspal. Dari hasil pengujian didapat nilai sebagai berikut:

Dilihat nilai stabilitas campuran $A C$ $W C$ dengan filler asbuton dan filler fly ash secara keseluruhan masih memenuhi persyaratan [8] dengan nilai $>800 \mathrm{~kg}$. Untuk campuran yang tanpa filler tidak memenuhi.

Nilai stabilitas tertinggi pada Campuran $A C$-WC terdapat pada persentase $2 \%$ filler fly ash dengan nilai $883,20 \mathrm{~kg}$. Sedangkan pada filler asbuton pada persentase yang sama didapat nilai 856,40 $\mathrm{kg}$. Ada persilangan garis grafik antara $f l y$ ash dan asbuton dari penggunaan filler $1 \%$ menuju ke $2 \%$ ini salah satu pengaruh penggunaan fly ash. menambah tinggi nilai stabilitas, jika di 3\% pengaruh filler fly ash tidak signitifikan datar saja.

Untuk nilai terendah pada campuran $A C$-WC tanpa penggunaan filler dengan nilai $792 \mathrm{~kg}$. Secara keselurahan bahwa nilai stabilitas pada campuran $A C$-WC dengan variasi filler nilai tertinggi pada filler fly ash didapat nilai $883,20 \mathrm{~kg}$. Sedangkan nilai terendah pada campuran $A C$-WC tanpa filler dengan nilai $792 \mathrm{~kg}$.

\section{Gambar 5. Grafik Stabilitas}

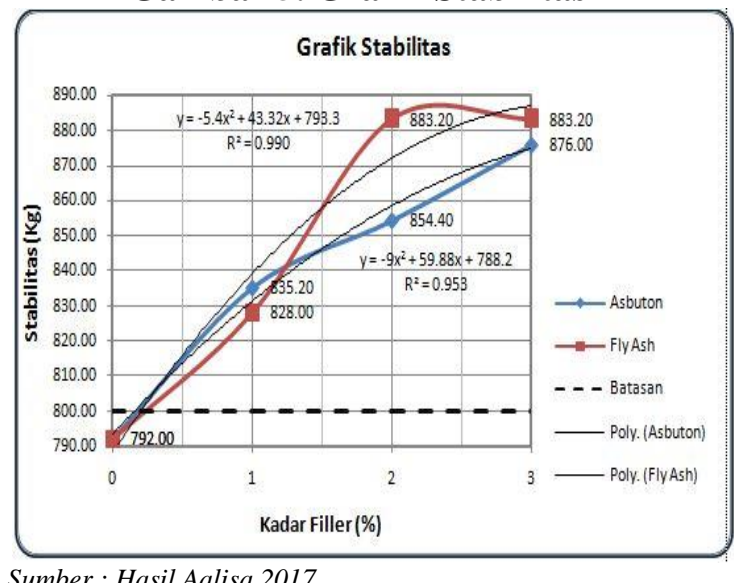

\subsection{Kelelehan}

Nilai kelelehan menyatakan besar deformasi atau penurunan campuran yang dipadatkan, yang diakibat besarnya beban yang bekerja diatasnya dan menunjukan 
tingkat kelenturan suatu perkerasan. Nilai kelelehan dipengaruhi oleh faktor aspal, viskositas aspal, gradasi, agregat tekstur permukaan agregat dan tingkat pemadatan. Nilai kelelehan yang disyaratkan adalah 2,0 sampai 4,0 [8], jika nilai kelelehan kurang dari 2,0 menyebabkan campuran mudah mengalami retak dan ber- alur karena sifat kaku.

Nilai kelelehan yang tertinggi ada pada campuran tanpa filler yaitu dengan nilai 3,43 sedangkan nilai terendah pada penggunaan filler $3 \%$ fly ash yaitu dengan nilai 3,0. Untuk filler asbuton $1 \%$ dan 3\% sangat kecil nilai sama dengan nilai 3,3 dan 3,3 . Secara keseluruhan untuk nilai kelelehan pada campuran $A C$ WC tanpa filler, filler asbuton berbutir dan filler fly ash memenuhi syarat [8] dengan nilai 2,0 $-4,0 \mathrm{~mm}$, sekalipun tidak konstan.

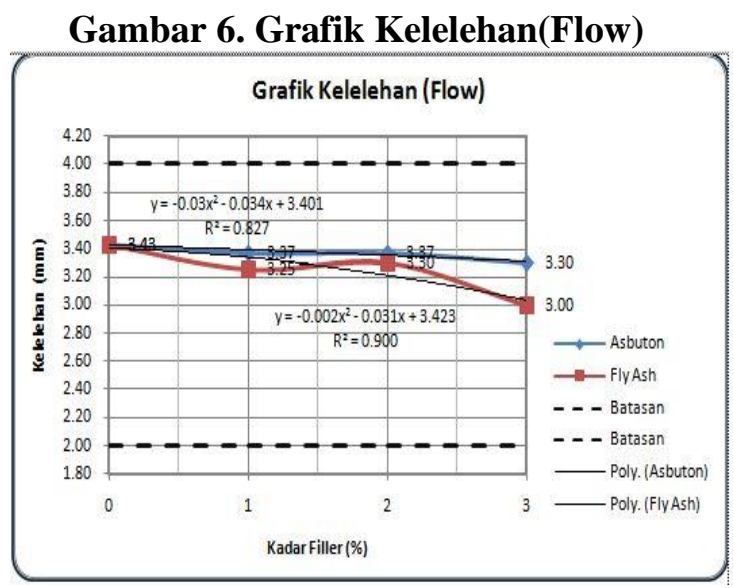

Sumber : Hasil Analisa 2017

\subsection{Marshall Quetient}

Nilai hasil bagi marshall dipengaruhi hasil bagi antara stabilitas yang terkoreksi dan nilai kelelehan. Nilai hasil bagi ini digunakan sebagai pedekatan terhadap tingkat kekakuan atau fleksibelitas suatu campuran. Semakin besar nilai hasil bagi marshall maka akan semakin kaku suatu campuran. Semakin kecil nilai hasil bagi marshall akan semakin lentur campuran tersebut [9]. Dari hasil pengujian didapat nilai sebagai berikut:

Nilai keseluruhan dari percobaan filler asbuton berbutir dan filler fly ash masih menunjukan nilai yang memenuhi syarat mulai dari filler 1\%, 2\% dan 3\% untuk filler asbuton berbutir masih memenuhi persyaratan [8]. Kemudian untuk filler $1 \%$, $2 \%$ dan 3\% untuk filler fly ash masih memenuhi persyaratan [8] dengan nilai $>250$ $\mathrm{kg} / \mathrm{mm}$. Ada persilangan garis grafik penggunaan filler fly ash dan asbuton dilihat dari grafik penggunaan fly ash di 3\% masih ada nilai kelenturan sedangkan pada asbuton $3 \%$ ada penurunan tingkat kelenturan berkurang. Untuk campuran $A C$ - $W C$ tanpa filler tidak memenuhi didapat nilai 236,5 $\mathrm{kg} / \mathrm{mm}$.

Gambar 7. Grafik Marshall Qoutient

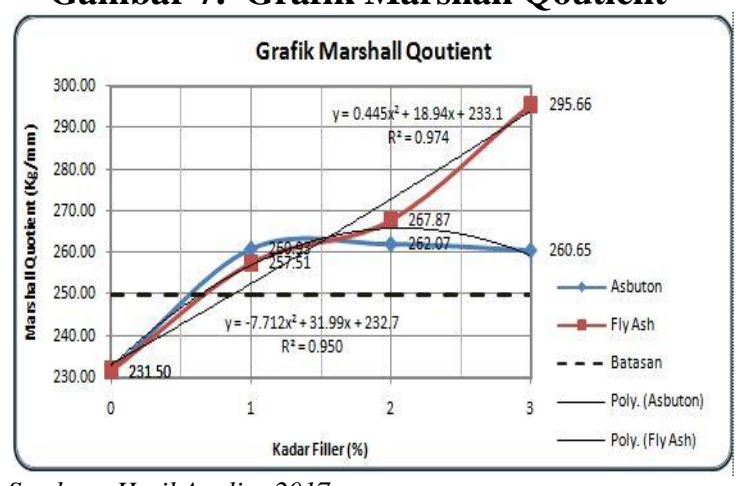

Sumber : Hasil Analisa 2017

\section{KESIMPULAN}

Berdasarkan hasil analisa data yang dilakukan dalam penelitian ini, maka dapat ditarik beberapa kesimpulan antara lain:

1. Untuk stabilitas filler fly ash lebih tinggi dengan nilai $884,30 \mathrm{~kg}$ bila dibandingkan dengan asbuton dengan nilai $877,14 \mathrm{~kg}$.

2. Bulk density filler asbuton lebih tinggi dengan nilai $2,287 \mathrm{gr} / \mathrm{cm}^{3}$ dibandingkan fly ash dengan nilai $2,263 \mathrm{gr} / \mathrm{cm}^{3}$. Untuk nilai rongga dalam campuran (VIM) yang tertinggi di campuran tanpa penggunaan filler 5,5\% sedangkan terendah pada penggunaan filler asbuton divariasi 3\% dengan nilai $3,47 \%$.

3. Pasir alam dapat digunakan tidak melampaui $15 \%$.

\section{DAFTAR PUSTAKA}

[1] Http://www.putra-ultimate.blogspot.com /2010/05/pengertian-aspal-betoncampuran-panas.html

[2] Sukirman, Silvia. 2003 Beton Aspal Campuran Panas Edisi 1 Penerbit Granit Jakarta. 
[3] Sukirman, Silvia. 1999. Perkerasan Lentur Jalan Raya. Bandung. Penerbit Nova.

[4] Direktorat Jenderal Bina Marga. 1987. Pelaksanaan Lapisan Aspal Beton (LASTON ) Untuk Jalan Raya. Jakarta. Yayasan Badan Penerbit PU.

[5] Soehartono, Ir. 2007. Tinjauan Penggunaan Asbuton Saat Ini dan Prospek ke Masa Depan. Jakarta.

[6] Puslitbang Teknologi Mineral Batu Bara Departemen ESDM 2003

[7] Laboratorium Pengujian BBPJN $V$. 2017. Laporan Design Mix Formula AC-WC Paket Preservasi Rekonstruksi Jalan Mangun Jaya - Batas Kabupaten Mura - Batas kabupaten Muba-Muara Beliti. Palembang. Balai Besar Pelaksanaan Jalan Nasional V.

[8] Kementerian Pekerjaan Umum. 2015. Spesifikasi Umum Tahun 2010 Revisi 3 Divisi 6. Jakarta. Kementerian Pekerjaan Umum Republik Indonesia.

[9] Direktorat Jenderal Bina Marga. 2010. Spesifikasi khusus Bina Marga. Jakarta. Departeman Pekerjaan Umum Republik Indonesia. 